\title{
The Geology, Geochemistry and Petrogenetic Studies of the Precambrian Basement Rocks around Iworoko, are and Afao Area, Southwestern Nigeria
}

\author{
OLUSIJI SAMUEL AYODELE \\ Department of Geology, Ekiti State University, P.M.B. 5363. Ado-Ekiti \\ Email: riksam2002@yahoo.com; riksam2002@gmail.com
}

\begin{abstract}
The geology, geochemistry and petrogenetic studies of the Precambrian basement rocks around Iworoko, Are and Afao Ekiti were carried out to determine their geochemical and petrogenetic characteristics. Three lithologies including migmatite-gneiss, granite gneiss and banded gneiss with a pegmatite dyke that occurred as an intrusion were recognized in the study area. A total of seventeen rock samples were collected from the study area which were described based on their field relationships. Ten fresh rock samples were later selected for geochemical analysis. The result of the geochemical analysis revealed that silica $\left(\mathrm{SiO}_{2}\right)$ is the most abundant major oxide when compared with other oxides present in all the rock samples analyzed with an average percentage composition of $66.31 \%$. The average percentage composition of other oxides present in all the rock samples are as follows; (16.41\%) $\mathrm{Al}_{2} \mathrm{O}_{3}$, (3.67\%) $\mathrm{Fe}_{2} \mathrm{O}_{3},(0.25 \%) \mathrm{CaO}$, (4.28\%) $\mathrm{K}_{2} \mathrm{O},(3.53 \%) \mathrm{Na}_{2} \mathrm{O},(1.75 \%)$ $\mathrm{MgO},(0.78 \%) \mathrm{P}_{2} \mathrm{O}_{5},(0.54 \%) \mathrm{TiO}_{2}$ and $(0.061 \%) \mathrm{MnO}$. The results of the trace and rare earth elements analyses revealed that Barium $(\mathrm{Ba})$ is the most abundant with an average value of $328.7 \mathrm{ppm}$ compared to other trace and rare earth elements present in the rock samples. The high concentration of barium in the migmatite-gneisses of the study area revealed the radioactive nature of this lithology. Petrological and chemical data suggests a sedimentary protolith, probably greywacke for the migmatite gneiss, gneiss and banded gneiss in the study area which may have been derived from a continental environment.
\end{abstract}

Keywords: Are; Afao; Iworoko; Lithologies; Geochemical plots; Statistics.

\section{INTRODUCTION}

Nigeria lies to the rest of the West Africa craton in the region of late Precambrian to Early Paleozoic orogenesis. The basement complex is made up of Precambrian rocks and the schist belts infolded in them. The Precambrian rocks of southwestern Nigeria is part of the Precambrian Basement complex of Nigeria, the Basement complex itself is made up of Gneiss-migmatite complex and the Pan African older Granite rocks. However, the lithologies in the study area include; migmatite-gneiss, granite-gneiss and banded gneiss. These rocks have undergone polycyclic deformation thereby causing the deformation of both the macro and micro structures. Secondary structures in rocks that can be used as clues to determine the geologic history of an area include; joints, folds, fractures and foliations etc. Some of these structures are not deformational but were formed at the same time the rocks were emplaced. A lot of literatures abound on the study of basement geology of Nigeria and its associated structures which include Anifowose et al (2007) who noted that joints ranging from minor to major ones are found in all the rock types, some of which are filled with quartz, feldspars or a combination of both. They lie generally in the NE-SW direction. Odeyem et al., (1999) also suggested that almost all the foliation exhibited by the rocks of southwestern Nigeria excluding the intrusive are tectonic in origin because pre-existing primary structures have been obliterated by subsequent deformation. Boesse and Ocan (1992) reported that the south western basement complex of Nigeria has been affected by three phases of deformation namely $D_{1}, D_{2}, D_{3}$. The first phase $D_{1}$ produced tight isoclinals folds while the second phase $D_{2}$ is characterized by more open folds of variable styles. Large vertical NNE-SSW trending fault zones are also related to the $\mathrm{D}_{2}$ event. $A$ minor $\mathrm{D}_{3}$ phase produced local NE-SW trending fault. The open metric folds are characterized by steeply dipping axial planes. These axial planes may not be accompanied by syntectonic foliation $S_{3}$ such as fracture, cleavages in quartzite or crenulation cleavages in mica schist. Oyawoye (1964), Rahaman (1976), Odeyemi (1977) also noted that the rocks in the study area show evidence of polyphase deformation with the plutonic episode of the Pan African event being the most pervasive. This study attempts to evaluate the geology, geochemical and petrogenetic characteristics of the Precambrian basement rocks of Iworoko, Are and Afao area, with the objective of understanding the geologic setting and geochemical composition of these rocks and the petrogenetic characteristics of the rocks in other to provide a baseline geo-information data for the study area.

The study area lies in Irepodun/Ifelodun area, north east of Ekiti State, and falls within latitudes $07^{0}$ $41^{1} \mathrm{~N}-07^{0} 43^{1} \mathrm{~N}$ and longitudes $05^{0} 15^{1} \mathrm{E}-05^{0} 18^{1} \mathrm{E}$ respectively (Fig.1). These include Iworoko, Are and Afao-Ekiti, with an area coverage of about $242.6 \mathrm{~km}^{2}$. The study area is generally accessible and motorable with availability of tarred and untarred roads which linked the towns and villages together in the area. Most of the outcrops are located in the thick forests in which the use of cutlass was essential in creating footpaths. The major 
towns around the study area include Ilokun, Ilupeju etc while the localities within Iworoko, Are and Afao-Ekiti were named after the features or events which occurred within each town amongst these include Ori oke Adura, Oke ode, oke iyanu etc. The settlement pattern in the study area is the nucleated type and the major occupation of the inhabitants are farming and trading.

\section{GEOLOGIC SETTING OF THE STUDY AREA}

Nigeria landmass forms part of the Pan African shield and is located between the West African craton to the East. The country lies between latitudes $6^{\circ} \mathrm{N}$ and $12^{\circ} \mathrm{N}$ and longitudes $4^{0} \mathrm{E}$ and $12^{\circ} \mathrm{E}$. The West African craton and Pan African events present Igneous/metamorphic structural framework of Africa consisting of Precambrian rocks that have been subjected to supracrustal plutonics. The basement complex of Nigeria lies to the rest of the West African craton in the region of late Paleozoic orogenesis. The basement complex extends westwards and is continous with the Dahomeyan of the Dahomey-Togo-Ghana region. To the east and south, the basement complex is covered by the Mesozoic -Recent of the Dahomey and Niger coastal basins. The Nigerian basement rocks are exposed in the North central, south western and eastern part of the country. Usually the basements are separated by sedimentary rocks except in the north central where they are continous into each other. For description purposes, the basement complex has been divided into four namely; north western zone, north central zone, south western zone and the eastern zone. Crystalline rocks which form the basement complex of Nigeria are exposed in about half of the country while the remaining half is covered by sedimentary rocks. (Fig.2). The Nigerian basement complex can broadly be classified into three units; the gneiss-migmatite complex, the metasedimentary schist belt and the older granite suite. The migmatite-gneiss complex consists of; Archean (3000Ma) and Paleoproterozoic (2000Ma) components (Oversby, 1975; Dada et al (1995) which form the floor on which the supracrustal (the schist) were deposited. Both "Basement" and "cover sequence" were subsequently deformed by the Pan African thermotectonic event (600Ma) (Ajibade et al 1987) to produce conformably structural relationships (Annor, 1986). This effectively obscured the age relationship between the two units and hinders definitive conclusions to the origins of the schist belts. As a result of the Pan African events (Kennedy, 1964), huge volumes of discordant granitoids termed as the older granites, granodiorites, syenites and adamellites were emplaced. Rahaman (1981) indicated the rocks have undergone a complex evolutionary

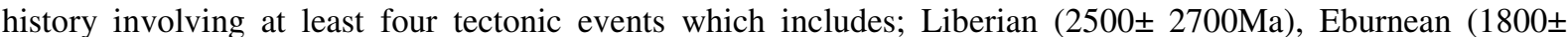
$2500 \mathrm{Ma})$, Kibaran $(1100 \pm 200 \mathrm{Ma})$ and Pan African $(600 \pm 150 \mathrm{Ma})$. Rahaman $(1988)$ also concluded that the Nigerian basement complex consists of six main lithological units with the following relative time relationships such as ( i) Migmatite-gneiss-quartzite complex (ii) Schist belts (iii) Charnokites (iv) Older granites ( Granitoids) (v) Volcanic, gabbroic and dioritic rocks (vi) Unmetamorphosed dolerite, basic and syenite dykes.

\section{LOCAL GEOLOGY OF THE STUDY AREA}

The study area is dominated by granite-gneiss, banded-gneiss and migmatite-gneiss respectively. These rocks are mostly metamorphic and belong to the Precambrian basement rocks of southwestern Nigeria, which itself is part of the basement rocks of Nigeria (Fig.3). The various lithologic units in the area are discussed below, while their field description and relationships are presented in Table.1.

\section{Migmatite-Gneiss-Quartzite Complex}

The migmatite-gneiss-quartzite complex occurs as ridges and highlands at Iworoko and Afao-Ekiti, but as valleys at Are Ekiti. Most of these rocks have been subjected to mechanical and chemical weathering. The migmatite-gneiss-quartzite complex is presumably the oldest group of rocks in the study area and the most widespread. Its occurrence is not restricted as it is found in the entire area of study. The texture of the migmatitegneiss-quartzite complex in the study area varies from fine grained to medium grained while the structures observed on the outcrop include folds, joints, cracks and veins. The dominant mineral assemblages of this rock include quartz, mica, plagioclase, and hornblende. The field relationships between the migmatite-gneiss-quartzite complex rocks and other surrounding rocks could not be easily ascertained as a result of thick vegetation.

\section{Granite-gneiss}

The granite-gneiss in the study area occurs as a hilly outcrop especially around Afao and Iworoko Ekiti. The texture of these rocks varies from fine to medium grained. The dominant mineral assemblages found in the granite-gneiss include quartz, feldspar, and mica, and the structures found on the outcrop are microfolds, veinlets and quartz veins. The surface of the outcrop has been subjected to exfoliation as a result of physical weathering. The granite-gneiss has a clear and sharp contact with the surrounding migmatite-gneiss-quartzite complex.

\section{Banded gneiss}

The banded gneiss extends across some parts of the study area particularly Iworoko and Afao. In these areas, the rocks are medium to coarse grained texturally and occur as a hill in the study area. Also, the rock is characterized by banding in which there is mineral alignment. The banding varies from about 1 centimeter to 3 centimeters in the banded varieties found in Are and Afao Ekiti. The rock is typified by clear fine banding which shows 
alternating white and black (hornblende, biotite) layers. Structures observed on this outcrop include folds, veins and pegmatite dyke, the pegmatite shows no zoning thus making it simple in nature with a width of about 32 centimeters. The present state of the rock is as a result of weathering.

\section{METHOD OF STUDY}

The method of study adopted for the different aspects of this work include field and laboratory operations. The field operations involve sample collection and the sampling method used is the grid-controlled type in which the base map of the area were divided into segments of $4 \mathrm{~cm}$ by $4 \mathrm{~cm}$ at a sampling density of one sample per $4 \mathrm{~km}^{2}$. A total of seventeen rock samples were collected from the study area which were lithologically described based on their field relationships after which were labeled properly and put in a sample bag for onward transmission to the laboratory. Ten (10) fresh samples were selected from the whole samples and were prepared for geochemical analysis for major, trace and rare earth elements determination. The rocks were initially crushed, using the jaw crusher into fragments and were pulverized later using the agate mortar. The four acid method of digestion was adopted in preparing the samples for geochemical analysis using $0.5 \mathrm{~g}$ of each sample and the analysis were carried out using the Atomic Absorption Spectrophotometer (AAS) at the Central Laboratory, University of Ibadan, Nigeria.

\section{RESULTS}

The results of the field data is presented in Table.1, while the major elements (Wt \%) determined is presented in Table.2. Trace and rare earth elements results are presented in Table. 3 while the average concentration of major elements is shown in Table. 4 .

\section{DISCUSSION}

The systematic geologic mapping, geochemical and petrogenetic studies of the Precambrian basement rocks in Iworoko, Are and Afao-Ekiti has been carried out and the overall results showed that $\mathrm{SiO}_{2}$ (silica) is by far the most abundant mineral in all the rock types with the highest percentage present in the migmatites $(66.2 \%)$ and the lowest in the banded gneisses $(63.0 \%)$, while $\mathrm{TiO}_{2}$ is the least abundant mineral with an average composition less than $1 \%$ in all the rock samples. The ferromagnesian compounds $(\mathrm{FeO}$ and $\mathrm{Mg} 0)$ have varying abundances in the rock samples. $\mathrm{Fe}_{2} \mathrm{O}_{3}$ value is higher in the migmatite gneisses $(4.65 \%)$ while the lowest percentage is present in banded gneisses $(2.67 \%)$, and the granite gneiss has percentage of $3.05 \%$; $\mathrm{MgO}$ is mostly abundant in the granite gneiss $(3.03 \%)$ because it contains more of mafic minerals than the other rocks. The banded gneisses have $1.81 \%$ while the migmatite gneisses have the lowest value of $\mathrm{Mg} 0$ (1.80\%). From this it shows these rock samples (migmatites and granite gneisses) must have been emplaced in a continental environment as explained by the plots of $\mathrm{TiO}_{2}-\mathrm{K}_{2} \mathrm{O}-\mathrm{P}_{2} \mathrm{O}_{5}$ (Fig.6). The results of the trace and rare earth elements show that $\mathrm{Ba}$ is the most abundant trace elements in the migmatite-gneiss. This indicated that the migmatite gneiss in the study area harbors some radioactive materials which are worth investigating. However, no mineral of economic importance has been reported in the area lately, but the migmatite gneisses in the study area could serve as a potential source of mineralization, especially radioactive minerals if well exploited. Also, the migmatite-gneiss in the study area could be chemically comparable to the metasediments of the south western Nigeria (Freeth, 1971, Rahaman and Ocan (1978). The plot of $\mathrm{SiO}_{2}$ versus $\mathrm{CaO}$ for the samples fell within the field of Francisian greywacke (Fig.4) (Brown, et al 1979) while the $\mathrm{Na}_{2} \mathrm{O} / \mathrm{Al}_{2} \mathrm{O}_{3}$ against $\mathrm{K}_{2} \mathrm{O} / \mathrm{Al}_{2} \mathrm{O}_{3}$ for the discrimination of sedimentary/metasedimentary and igneous series (Fig. 5) by Garrels and Mackenzie, 1971 showed that majority of the samples plotted were within the sedimentary field. Also, The $\mathrm{TiO}_{2}-\mathrm{K}_{2} 0-\mathrm{P}_{2} \mathrm{O}_{5}$ plot (Pearce et al, 1975) (Fig. 6 ) confirmed the continental nature of the sediments. The range and mean concentration (ppm) of the trace and rare earth elements present (Table.4 and Fig.7) indicated that Barium (Ba) has the range of $36-458 \mathrm{ppm}$ with an average value of $328.7 \mathrm{ppm}$. Migmatite gneiss has the highest concentration of $\mathrm{Ba} 458 \mathrm{ppm}$ while the pegmatite has the lowest concentration of Ba 36ppm. Chromium content ranges from 22 - 136ppm with an average value of $70.8 \mathrm{ppm}$ which is quite high. This high concentration in the samples could be responsible for the presence of some ultramafic bodies in the migmatite-gneiss. The pegmatite also contains fairly equal amounts of $\mathrm{Cu}, \mathrm{Ga}$, $\mathrm{Cr}$, As, $\mathrm{Pb}$ compared to the migmatite-gneisses.

\section{CONCLUSION AND RECOMMENDATION}

The geochemical and geological studies of the basement rocks in Iworoko, Are and Afao Ekiti, south western Nigeria has been studied. Through the results acquired from this analysis, it can be concluded that some of the trace and rare earth elements detected are radioactive in nature. Petrological and geochemical data interpreted strongly indicated a sedimentary protolith, probably greywacke for the migmatite gneisses, granite gneiss and banded gneisses of the Iworoko, Are and Afao Ektit area. The greywacke sediments may have been derived from continental source. It is recommended that the inhabitants should be quarantined against possible exposure to radioactive elements which could cause infant mortality, mutations, and carcinogenic radiations emanating from 
the area. Furthermore, the level of radioactivity of the migmatite gneiss in the area should be ascertained by carrying out radioactive survey program of the entire area.

\section{AKNOWLEDGEMENT}

I hereby acknowledge the efforts of Akinniyi Richard Akinwale, who assisted me during the geologic field mapping exercise of this research and whose immense contribution to this work is highly appreciated. Thank you very much.

\section{References}

Ajibade, A.C. (1987). The Origin of older granites of Nigeria. Some evidences from Zungeru region. Nigeria Journal, Mineral and Geology. pp. 223-230.

Anifowose, A.Y.B. and Borode, A.M., (2007). Photogeological study of the fold structure in Okemesi area, southwestern Nigeria. Journal of Mining and Geology. Volume 43 (2), pp. 125-130.

Annor, E.A., (1986). A structural classification of the Precambrian basement complex of Nigeria. Journal of Mining and Geology. Volume 7, No.2, pp. 42-47.

Boesse, S. and Ocan, O. (1992). Geology and evolution of the Ife-Ilesha Schist belt, southwestern Nigeria. In Benin-Nigeria Geotraverse. International Meeting on the Proterozoic Geology and Tectonics of High Grade Terrain. IGCP 215, pp. 123-129.

Brown, E.H., Babcock, R.S., Clark, M.D. and Livingstone, D.E., (1979). Geology of the older Precambrian rocks of the Grand Canyon, I, Petrology and Structure of the Vishu Complex. Precambrian Research. 8: 219-241.

Dada, S.S., Briqueu, I and Birck, J.L., (1998). Primordial crustal growth in northern Nigeria; Preliminary Rb-Sr and Sm-Nd constraints from Kaduna migmatite-gneiss complex. Journal of Mining and Geology. Volume 34, pp.16.

Dada, S.S., and Rahaman, M.A. (1995). Archean-Lower Paleozoic Crustal evolution in Nigeria. African Geoscience Review, Volume.2, pp. 219-225.

Freeth, S.J. (1971). Geochemical and related studies of West African igneous and metamorphic rocks. Ph.D. Thesis, University of Ibadan. 240p.

Garrels, R.M. \& Mackenzie, F.T. (1971). Evolution of sedimentary rocks. W.W. Norton and Company, Incorporated. New York, 394p.

Kennedy, W.Q. (1964). The structural differentiation of Africa in the Pan African \pm 500 Ma. tectonic episode, In: $8^{\text {th }}$ Annual Report of the Research Institute of African Geology, Leeds University, UK, 128.

Odeyemi, I.B., Anifowose, A.Y.B., and Asiwaju-Bello, Y.A., (1999). Multi-technique graphical analysis of fractures from remotely-sensed images of basement region of Nigeria. Journal of Mining and Geology, 35 (1) pp. 9-21.

Odeyemi, I.B. (1977). The basement rocks of Bendel state of Nigeria. Unpublished Ph.D. 


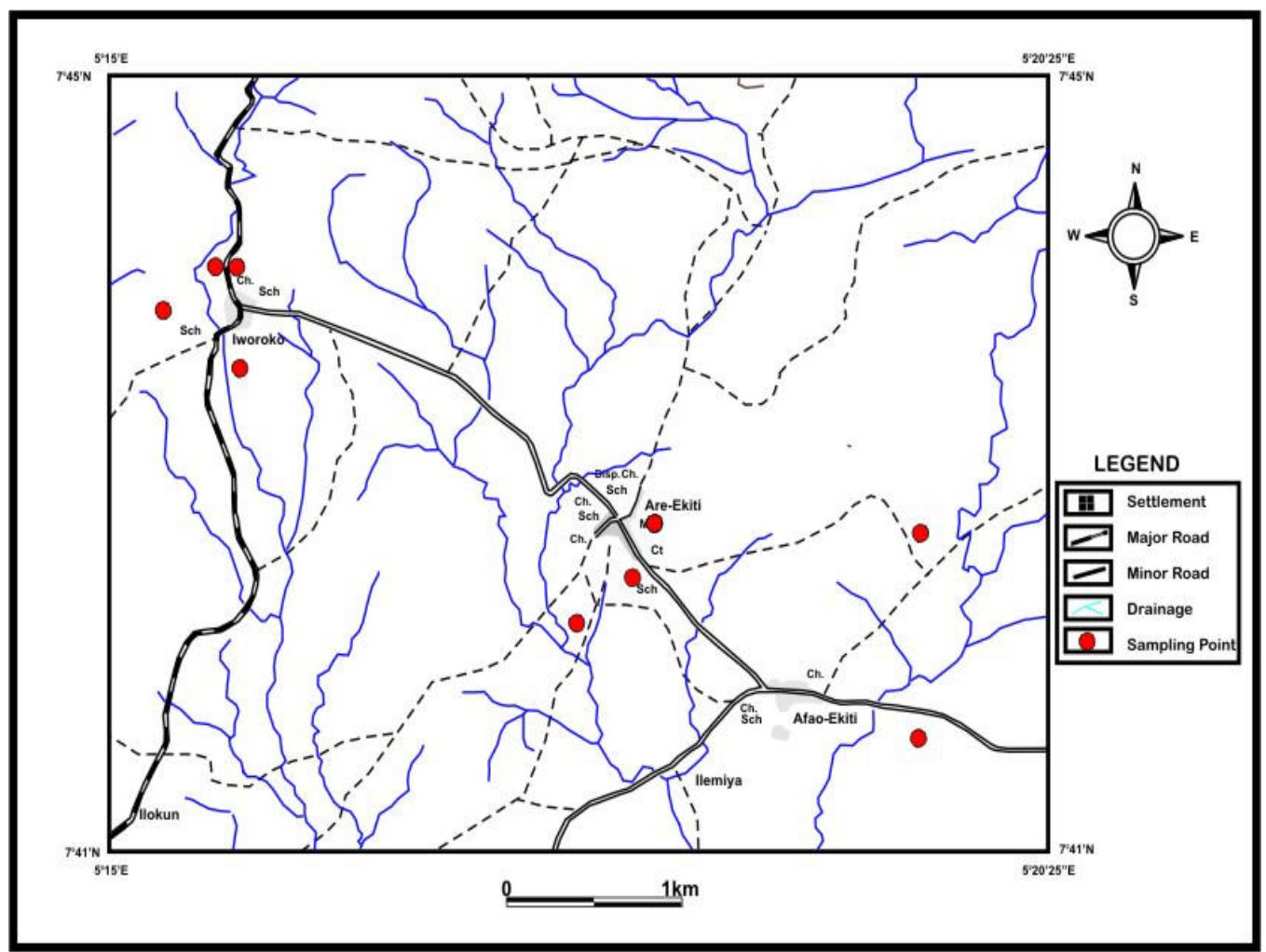

Fig.1. Location map of the study area showing rock sampling points.

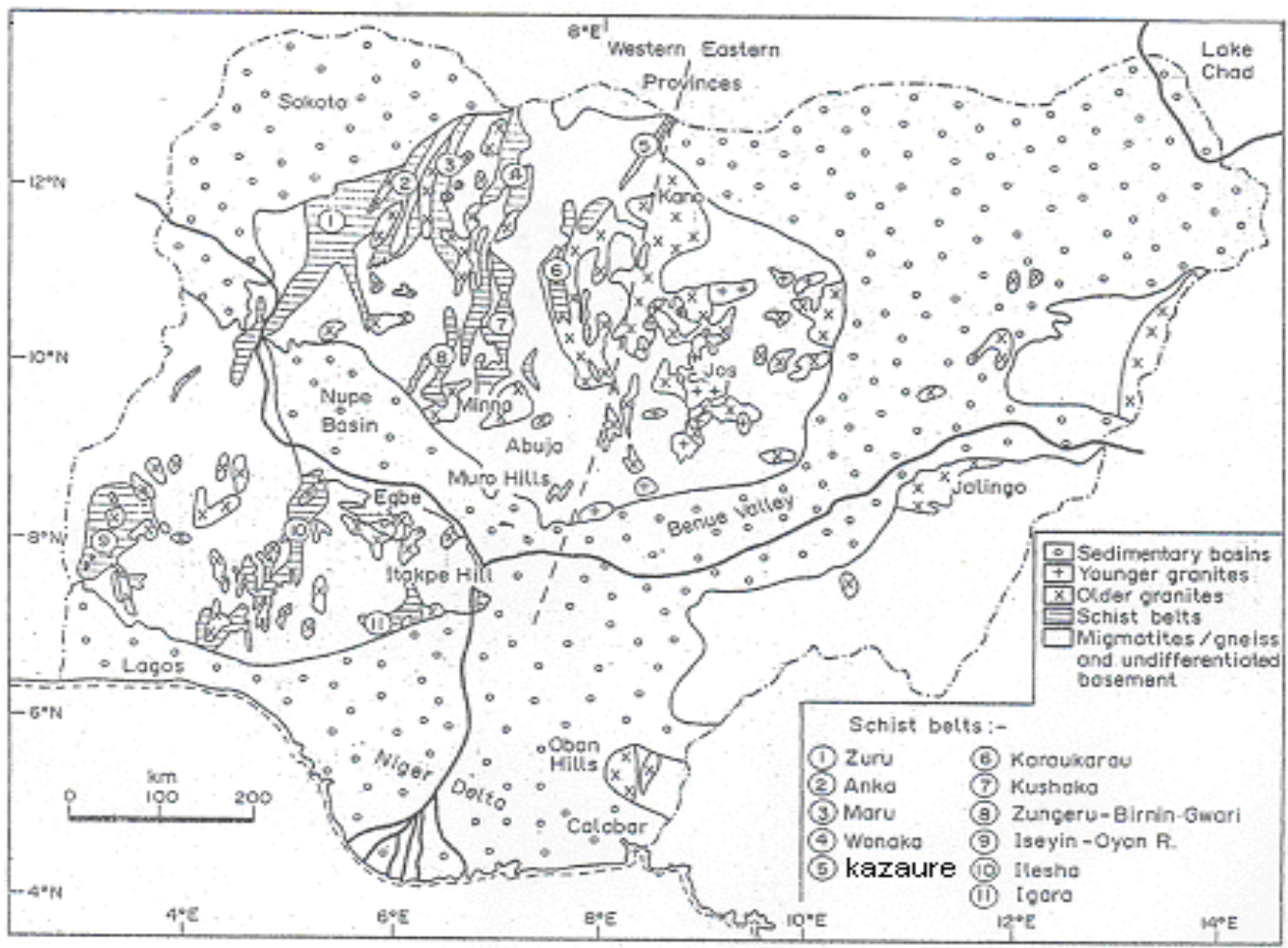

Fig.2. Generalized Geological Map of the Crystalline Rocks of Nigeria (After Rahaman, 1988) 


\begin{tabular}{|c|c|c|c|c|c|c|c|}
\hline $\mathbf{S} / \mathbf{N}$ & Location & Longitude & Latitude & Lithology & Texture & Structure & Dip \\
\hline 1 & $\begin{array}{l}\text { Ori-Oke } \\
\text { Adura } \\
\text { Iworoko }\end{array}$ & $\begin{array}{l}07^{0} \\
494^{\prime}\end{array}$ & $\begin{array}{ll}05^{0} & 15 \\
756^{\prime} & \end{array}$ & $\begin{array}{l}\text { Granite } \\
\text { Gneiss }\end{array}$ & $\begin{array}{l}\text { Medium to } \\
\text { Fine Grained }\end{array}$ & $\begin{array}{l}\text { Cracks, Joints, } \\
\text { Dykes, e.t.c. }\end{array}$ & \\
\hline 2 & $\begin{array}{l}\text { Behind } \\
\text { Iworoko } \\
\text { mosque }\end{array}$ & $\begin{array}{l}07^{0} \\
018^{\prime}\end{array}$ & $\begin{array}{ll}05^{0} & 15 \\
738^{\prime} & \end{array}$ & $\begin{array}{l}\text { Granite } \\
\text { Gneiss }\end{array}$ & $\begin{array}{l}\text { Fine to } \\
\text { Medium grain }\end{array}$ & $\begin{array}{l}\text { Veins, Veinlets, } \\
\text { Folds e.t.c. }\end{array}$ & \\
\hline 3 & $\begin{array}{l}\text { Behind } \\
\text { Iworoko } \\
\text { Grammer } \\
\text { School }\end{array}$ & $\begin{array}{l}07^{0} \\
794^{\prime}\end{array}$ & $\begin{array}{ll}05^{0} & 15 \\
315^{\prime} & \end{array}$ & $\begin{array}{l}\text { Migmatite } \\
\text { Gneiss }\end{array}$ & $\begin{array}{l}\text { Medium to } \\
\text { Fine Grain }\end{array}$ & $\begin{array}{l}\text { Quartz Vein, Cracks, } \\
\text { Folds, Dykes, } \\
\text { Exfoliation }\end{array}$ & \\
\hline 4 & Eniafe road & $\begin{array}{l}07^{0} \\
020^{\prime}\end{array}$ & $\begin{array}{ll}05^{0} & 15 \\
615^{\prime} & \end{array}$ & $\begin{array}{l}\text { Granite } \\
\text { Gneiss }\end{array}$ & $\begin{array}{l}\text { Medium to } \\
\text { coarse grain }\end{array}$ & $\begin{array}{l}\text { Folds, Veinlets, } \\
\text { Quartz veins }\end{array}$ & \\
\hline 5 & $\begin{array}{l}\text { Off Iworoko } \\
\text { Are road }\end{array}$ & $\begin{array}{l}07^{0} \\
058^{\prime}\end{array}$ & $\begin{array}{ll}05^{0} & 15 \\
425^{\prime} & \\
\end{array}$ & $\begin{array}{l}\text { Granite } \\
\text { Gneiss }\end{array}$ & $\begin{array}{l}\text { Fine to } \\
\text { Medium grain }\end{array}$ & Veins, Dykes. & \\
\hline 6 & $\begin{array}{l}\text { Aba Sunday } \\
\text { Are }\end{array}$ & $\begin{array}{l}07^{0} \\
375^{\prime}\end{array}$ & $\begin{array}{ll}05^{0} & 17 \\
114^{\prime} & \\
\end{array}$ & $\begin{array}{l}\text { Migmatite } \\
\text { Gneiss }\end{array}$ & $\begin{array}{l}\text { Medium to } \\
\text { coarse grain }\end{array}$ & $\begin{array}{l}\text { Exfoliation, Veinlet, } \\
\text { Fold, Veins }\end{array}$ & \\
\hline 7 & $\begin{array}{l}\text { Behind } \\
\text { OBA's } \\
\text { Palace Are }\end{array}$ & $\begin{array}{l}07^{0} \\
691^{\prime}\end{array}$ & $\begin{array}{ll}05^{0} & 18 \\
147^{\prime} & \end{array}$ & $\begin{array}{l}\text { Banded } \\
\text { gneiss }\end{array}$ & $\begin{array}{l}\text { Medium to } \\
\text { coarse grain }\end{array}$ & $\begin{array}{l}\text { Solution hole, } \\
\text { Banding, Lineation, } \\
\text { Exfoliation }\end{array}$ & $42^{0}$ \\
\hline 8 & $\begin{array}{l}\text { Oke Ode } \\
\text { Are }\end{array}$ & $\begin{array}{l}07^{0} \\
174^{\prime}\end{array}$ & $\begin{array}{ll}05^{0} & 17 \\
698^{\prime} & \end{array}$ & $\begin{array}{l}\text { Migmatite } \\
\text { Gneiss }\end{array}$ & $\begin{array}{l}\text { Medium to } \\
\text { coarse grain }\end{array}$ & $\begin{array}{l}\text { Exfoliation, } \\
\text { Lineation, solution } \\
\text { hole }\end{array}$ & $42^{0}$ \\
\hline 9 & Oke Isoro & $\begin{array}{l}07^{0} \\
158^{\prime} \\
\end{array}$ & $\begin{array}{ll}05^{0} & 17 \\
410^{\prime} & \\
\end{array}$ & $\begin{array}{l}\text { Migmatite } \\
\text { Gneiss }\end{array}$ & $\begin{array}{l}\text { Medium to } \\
\text { coarse grain }\end{array}$ & $\begin{array}{l}\text { Fold, Dyke, Veins, } \\
\text { Xenolith }\end{array}$ & \\
\hline 10 & $\begin{array}{ll}\text { Off } & \text { Isara } \\
\text { road } & \\
\end{array}$ & $\begin{array}{l}07^{0} \\
410^{\prime}\end{array}$ & $\begin{array}{ll}05^{0} & 18 \\
020^{\prime} & \\
\end{array}$ & $\begin{array}{l}\text { Migmatite } \\
\text { Gneiss }\end{array}$ & $\begin{array}{l}\text { Fine to } \\
\text { Medium grain }\end{array}$ & Fold, Dyke, Veinlets, & \\
\hline 11 & Isara Are & $\begin{array}{l}07^{0} \\
310^{\prime}\end{array}$ & $\begin{array}{ll}05^{0} & 17 \\
512^{\prime} & \\
\end{array}$ & $\begin{array}{l}\text { Migmatite } \\
\text { Gneiss }\end{array}$ & $\begin{array}{l}\text { Fine to } \\
\text { Medium grain }\end{array}$ & $\begin{array}{l}\text { Solution hole, Fold, } \\
\text { Veinlets }\end{array}$ & \\
\hline 12 & $\begin{array}{l}\text { Afao round } \\
\text { about }\end{array}$ & $\begin{array}{l}07^{0} \\
647^{\prime}\end{array}$ & $\begin{array}{ll}05^{0} & 19 \\
593^{\prime} & \end{array}$ & $\begin{array}{l}\text { Granite } \\
\text { Gneiss }\end{array}$ & $\begin{array}{l}\text { Medium to } \\
\text { Coarse grain }\end{array}$ & $\begin{array}{l}\text { Folds, Dyke, Vein, } \\
\text { Solution hole }\end{array}$ & \\
\hline 13 & $\begin{array}{l}\text { Behind Oke } \\
\text { iyanu Afao }\end{array}$ & $\begin{array}{l}07^{0} \\
578^{\prime}\end{array}$ & $\begin{array}{ll}05^{0} & 19 \\
669^{\prime} & \end{array}$ & $\begin{array}{l}\text { Granite } \\
\text { Gneiss }\end{array}$ & $\begin{array}{l}\text { Medium to } \\
\text { Coarse grain }\end{array}$ & $\begin{array}{l}\text { Folds, Vein, Cracks, } \\
\text { Solution hole }\end{array}$ & \\
\hline 14 & $\begin{array}{ll}\text { Oke } & \text { Iyanu } \\
\text { Afao } & \\
\end{array}$ & $\begin{array}{l}07^{0} \\
249^{\prime}\end{array}$ & $\begin{array}{ll}05^{0} & 19 \\
405^{\prime} & \\
\end{array}$ & $\begin{array}{l}\text { Granite } \\
\text { Gneiss }\end{array}$ & $\begin{array}{l}\text { Coarse to Fine } \\
\text { grain }\end{array}$ & $\begin{array}{l}\text { Folds, Fracture, } \\
\text { Solution hole }\end{array}$ & \\
\hline 15 & $\begin{array}{l}\text { Igbimo road, } \\
\text { Afao }\end{array}$ & $\begin{array}{l}07^{0} \\
158^{\prime}\end{array}$ & $\begin{array}{ll}05^{0} & 20 \\
684^{\prime} & \\
\end{array}$ & $\begin{array}{l}\text { Granite } \\
\text { Gneiss }\end{array}$ & $\begin{array}{l}\text { Coarse to Fine } \\
\text { grain }\end{array}$ & Vein, Solution hole. & \\
\hline 16 & $\begin{array}{l}\text { Off Igbimo } \\
\text { road, Afao }\end{array}$ & $\begin{array}{l}07^{0} \\
206^{\prime}\end{array}$ & $\begin{array}{ll}05^{0} & 20 \\
409^{\prime} & \\
\end{array}$ & $\begin{array}{l}\text { Granite } \\
\text { Gneiss }\end{array}$ & $\begin{array}{l}\text { Fine to coarse } \\
\text { grain }\end{array}$ & $\begin{array}{l}\text { Dyke, Vein, Solution } \\
\text { hole }\end{array}$ & \\
\hline 17 & $\begin{array}{l}\text { Ilemiya } \\
\text { road, Afao }\end{array}$ & $\begin{array}{l}07^{0} \\
640^{\prime}\end{array}$ & $\begin{array}{ll}05^{0} & 19 \\
680^{\prime} & \\
\end{array}$ & $\begin{array}{l}\text { Migmatite } \\
\text { Gneiss }\end{array}$ & $\begin{array}{l}\text { Medium to } \\
\text { fine grain }\end{array}$ & Dyke, Cracks, Vein. & \\
\hline
\end{tabular}




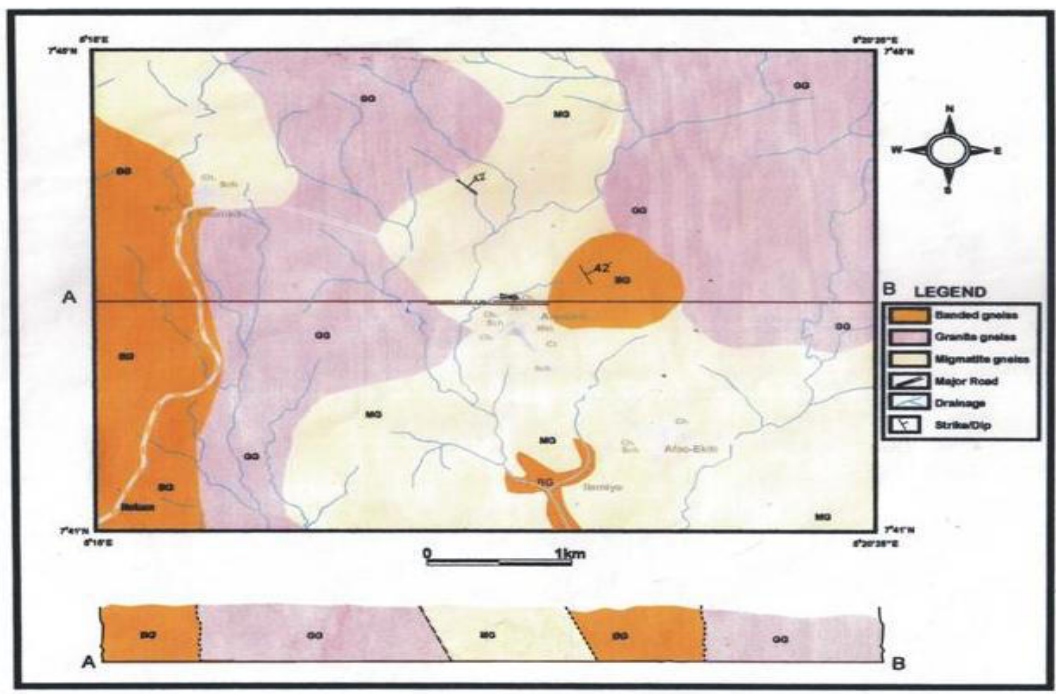

\begin{tabular}{|l|l|l|l|l|l|l|l|l|l|l|}
\hline Oxides & $\mathbf{S i O}_{2}$ & $\mathbf{A l}_{\mathbf{2}} \mathrm{O}_{\mathbf{3}}$ & $\mathbf{F e}_{\mathbf{2}} \mathrm{O}_{\mathbf{3}}$ & $\mathbf{T i O}_{2}$ & $\mathbf{C a O}$ & $\mathbf{P}_{\mathbf{2}} \mathbf{O}_{\mathbf{5}}$ & $\mathbf{K}_{\mathbf{2}} \mathbf{O}$ & $\mathbf{M n O}$ & $\mathbf{M g O}$ & $\mathbf{N a}_{\mathbf{2}} \mathbf{O}$ \\
\hline Migmatite gneiss & 66.2 & 15.5 & 4.65 & 0.53 & 2.12 & 0.68 & 5.0 & 0.078 & 1.80 & 3.24 \\
& & & & & & & & & & \\
\hline Granite gneiss & 65.20 & 17.10 & 3.05 & 0.53 & 3.08 & 1.02 & 3.75 & 0.05 & 3.03 & 3.28 \\
\hline
\end{tabular}

Fig.3. Geologic and cross-section map of the study area.

\begin{tabular}{|l|l|l|l|l|l|l|l|l|l|l|}
\hline $\begin{array}{c}\text { Trace and } \\
\text { rare earth } \\
\text { elements }\end{array}$ & $\begin{array}{c}\text { Are- } \\
\text { Ekiti }\end{array}$ & $\begin{array}{c}\text { Are- } \\
\text { Ekiti }\end{array}$ & $\begin{array}{c}\text { Iworoko- } \\
\text { Ekiti }\end{array}$ & $\begin{array}{c}\text { Afao- } \\
\text { Ekiti }\end{array}$ & $\begin{array}{c}\text { Iworoko- } \\
\text { Ekiti }\end{array}$ & $\begin{array}{c}\text { Iworoko- } \\
\text { Ekiti }\end{array}$ & $\begin{array}{l}\text { Are- } \\
\text { Ekiti }\end{array}$ & $\begin{array}{l}\text { Are- } \\
\text { Ekiti }\end{array}$ & $\begin{array}{c}\text { Iworoko- } \\
\text { Ekiti }\end{array}$ & $\begin{array}{c}\text { Afao- } \\
\text { Ekiti }\end{array}$ \\
\hline $\mathrm{Ba}$ & 36 & 372 & 382 & 316 & 458 & 346 & 358 & 446 & 237 & 336 \\
\hline $\mathrm{Ga}$ & 39 & 17 & 38 & 44 & 39 & 37 & 34 & 37 & 26 & 29 \\
\hline $\mathrm{Cu}$ & 14 & 45 & 25 & 30 & 25 & 49 & 29 & 33 & 15 & 29 \\
\hline $\mathrm{Cr}$ & 52 & 131 & 109 & 96 & 48 & 136 & 42 & 46 & 22 & 26 \\
\hline $\mathrm{As}$ & 62 & 57 & 4 & 6 & 61 & 52 & 4 & 3 & 6 & 3 \\
\hline $\mathrm{Pb}$ & 61 & 88 & 15 & 18 & 36 & 28 & 246 & 78 & 60 & 86 \\
\hline
\end{tabular}

Table.3: Trace And Rare Earth Elements In (Ppm)

\begin{tabular}{|l|l|l|l|l|l|l|l|l|l|l|}
\hline $\begin{array}{l}\text { Major } \\
\text { elements }\end{array}$ & $\begin{array}{l}\text { Are- } \\
\text { Ekiti }\end{array}$ & $\begin{array}{l}\text { Are- } \\
\text { Ekiti }\end{array}$ & $\begin{array}{l}\text { Iworoko- } \\
\text { Ekiti }\end{array}$ & $\begin{array}{l}\text { Afao- } \\
\text { Ekiti }\end{array}$ & $\begin{array}{l}\text { Iworoko- } \\
\text { Ekiti }\end{array}$ & $\begin{array}{l}\text { Iworoko- } \\
\text { Ekiti }\end{array}$ & $\begin{array}{l}\text { Are- } \\
\text { Ekiti }\end{array}$ & $\begin{array}{l}\text { Are- } \\
\text { Ekiti }\end{array}$ & $\begin{array}{l}\text { Iworoko- } \\
\text { Ekiti }\end{array}$ & $\begin{array}{l}\text { Afao- } \\
\text { Ekiti }\end{array}$ \\
\hline $\mathrm{SiO}_{2}$ & 74.97 & 65.46 & 64.85 & 66.36 & 60.30 & 70.07 & 65.20 & 64.30 & 69.90 & 61.66 \\
\hline $\mathrm{Al}_{2} \mathrm{O}_{5}$ & 15.11 & 17.00 & 15.20 & 15.85 & 14.83 & 14.16 & 17.10 & 17.40 & 15.99 & 21.49 \\
\hline $\mathrm{Fe}_{2} \mathrm{O}_{3}$ & 0.40 & 7.60 & 7.20 & 4.67 & 4.77 & 3.39 & 3.05 & 3.15 & 0.27 & 2.18 \\
\hline $\mathrm{TiO}_{3}$ & 0.01 & 1.08 & 0.76 & 0.58 & 0.74 & 0.01 & 0.53 & 0.75 & 0.01 & 0.95 \\
\hline $\mathrm{CaO}$ & 0.27 & 1.72 & 2.90 & 3.02 & 4.75 & 0.09 & 3.08 & 5.88 & 0.26 & 3.68 \\
\hline $\mathrm{P}_{2} \mathrm{O}_{5}$ & 0.22 & 0.06 & 0.17 & 1.21 & 1.36 & 0.29 & 1.02 & 0.95 & 0.96 & 1.24 \\
\hline $\mathrm{K}_{2} \mathrm{O}$ & 3.53 & 4.25 & 2.82 & 2.91 & 3.47 & 8.42 & 3.75 & 1.75 & 8.30 & 3.56 \\
\hline $\mathrm{MnO}$ & 0.04 & 0.02 & 0.15 & 0.10 & 0.09 & 0.06 & 0.05 & 0.03 & 0.05 & 0.02 \\
\hline $\mathrm{MgO}$ & 0.11 & 1.40 & 2.45 & 2.32 & 4.35 & 0.10 & 3.03 & 2.20 & 0.10 & 1.41 \\
\hline $\mathrm{Na} 2 \mathrm{O}$ & 5.28 & 2.87 & 3.15 & 3.08 & 4.06 & 2.76 & 3.28 & 3.76 & 3.57 & 3.45 \\
\hline $\mathrm{Total}$ & 99.94 & 101.46 & 99.65 & 100.1 & 98.72 & 99.35 & 100.09 & 100.1 & 99.41 & 99.64 \\
\hline
\end{tabular}




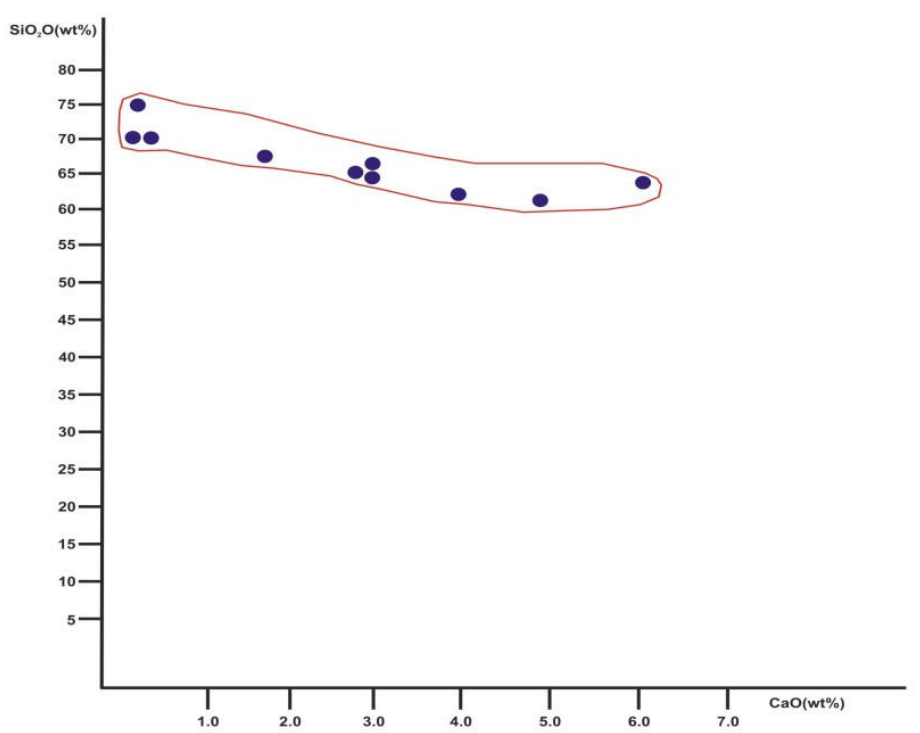

Fig. 4. Sios ${ }_{2}$-CaO Plot for Iworoko Are and Afao Ekiti Gneisses (Field of Francisian Greywacke after Brown et. al 1979).

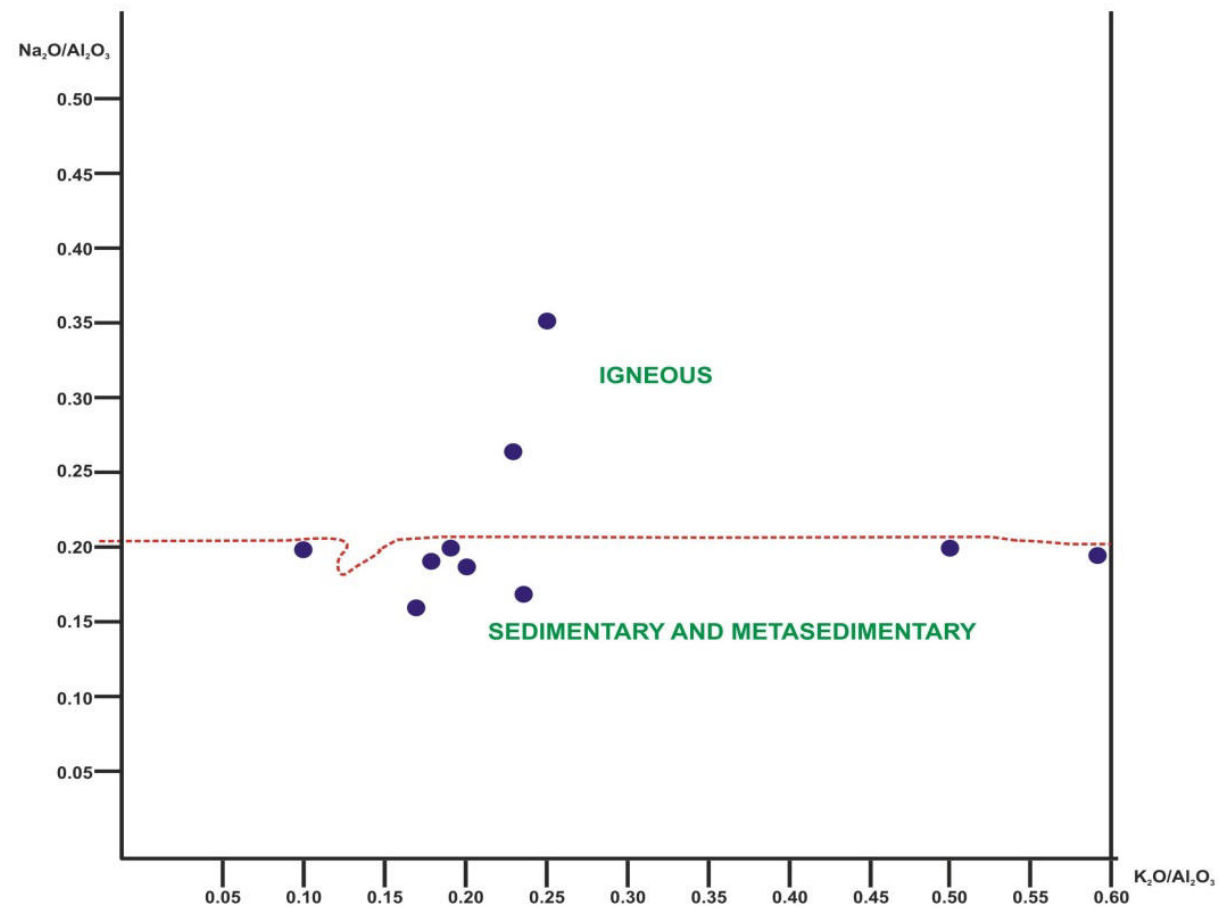

Fig. 5. $\mathrm{Na}_{2} \mathrm{O} / \mathrm{Al}_{2} \mathrm{O}_{3} \mathrm{Vs} \mathrm{K}_{2} \mathrm{O} / \mathrm{Al}_{2} \mathrm{O}_{3}$ Variation diagram fields of igneous and sedimentary/metasedimentry rocks after Garrels and Mackenzie (1971) 


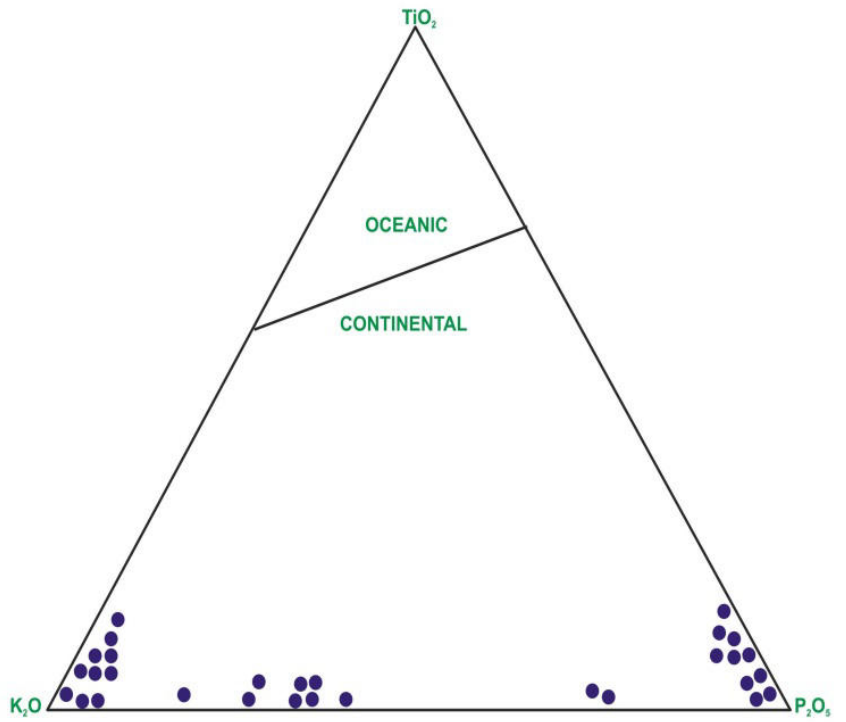

Fig. 6. $\mathrm{TiO}_{2}-\mathrm{K}_{2} \mathrm{O}-\mathrm{P}_{2} \mathrm{O}_{5}$ plot of the rocks from Iworoko, Are and Afao Ekiti (Pearce et al., 1975)

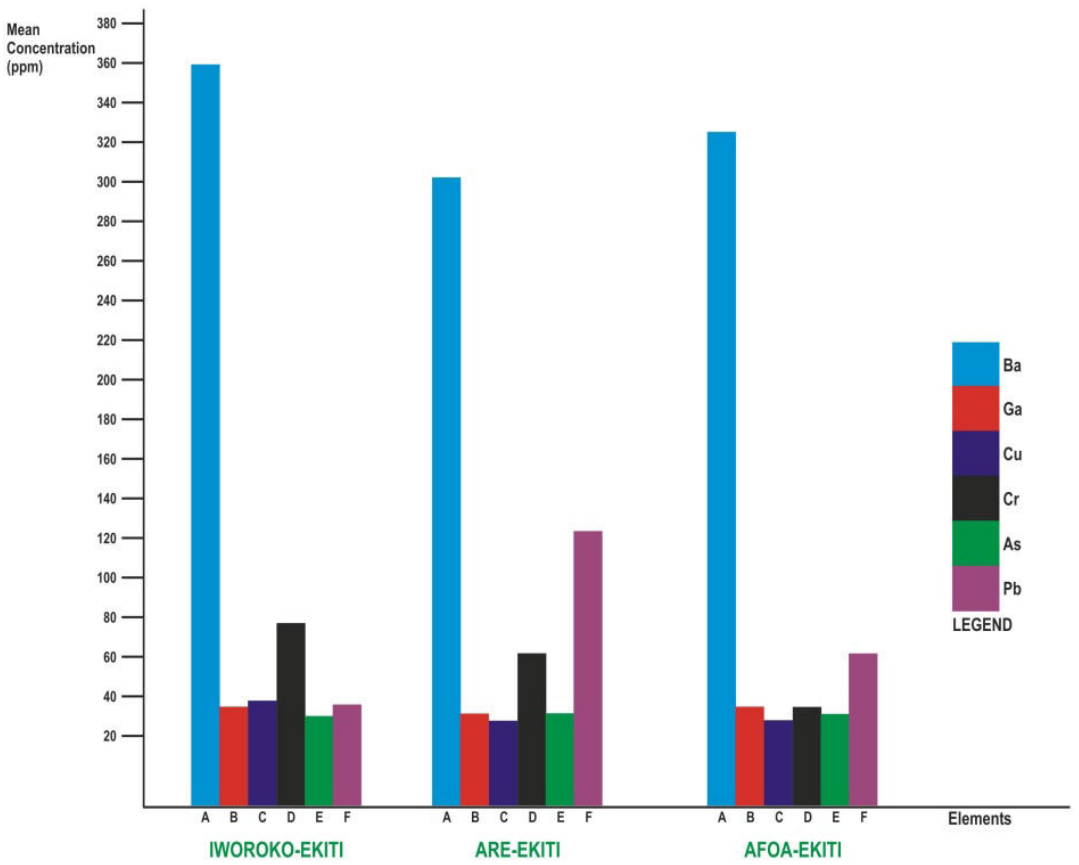

Fig. 7. Histogram of mean concentration of the trace and rare-earth elements in the study area. 
The IISTE is a pioneer in the Open-Access hosting service and academic event management. The aim of the firm is Accelerating Global Knowledge Sharing.

More information about the firm can be found on the homepage:

http://www.iiste.org

\section{CALL FOR JOURNAL PAPERS}

There are more than 30 peer-reviewed academic journals hosted under the hosting platform.

Prospective authors of journals can find the submission instruction on the following page: http://www.iiste.org/journals/ All the journals articles are available online to the readers all over the world without financial, legal, or technical barriers other than those inseparable from gaining access to the internet itself. Paper version of the journals is also available upon request of readers and authors.

\section{MORE RESOURCES}

Book publication information: http://www.iiste.org/book/

Academic conference: http://www.iiste.org/conference/upcoming-conferences-call-for-paper/

\section{IISTE Knowledge Sharing Partners}

EBSCO, Index Copernicus, Ulrich's Periodicals Directory, JournalTOCS, PKP Open Archives Harvester, Bielefeld Academic Search Engine, Elektronische Zeitschriftenbibliothek EZB, Open J-Gate, OCLC WorldCat, Universe Digtial Library, NewJour, Google Scholar

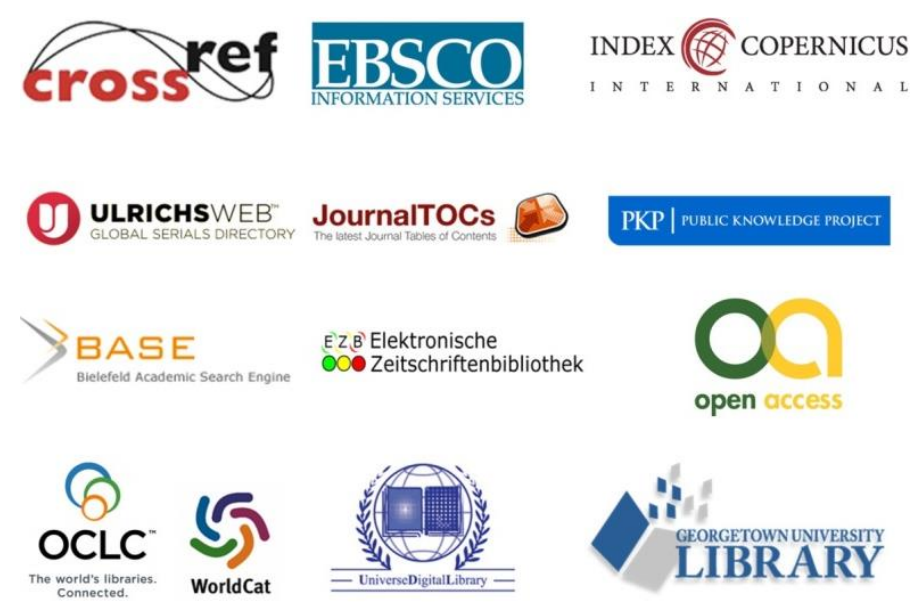

